\title{
Influence of passive house technology on time and cost of construction investment
}

\author{
Magdalena Apollo ${ }^{1, *}$, Emilia Miszewska-Urbańska ${ }^{1}$ \\ ${ }^{1}$ Gdańsk University of Technology, Faculty of Civil and Environmental Engineering, Department \\ of Metal Structures and Construction Management, Narutowicza 11/12 Str., 80-233 Gdańsk, Poland
}

\begin{abstract}
Due to the changes in the energy standards for housing in Poland there are many concerns. Is the standard required by the regulation achievable and if it is, then at what cost?

There are many solutions to construct a building in line with the requirements of passive house technology. They are differentiated by price and time required for implementation. This study is based on the solution proposed by one of Polish companies, offering technologically integrated products allowing, according to the producer, to build passive houses faster and easier. The goal of this study was to confront producer's claim with reality by comparing time and cost of the same investment using conventional and passive house technology. The basis for time and cost analysis was a basic detached house design, partially modified with regards to materials and technology used.

Conclusions of the study are based on the comparison of the two Gantt charts defined in Ms Project. Construction schedule was used to analyse the duration of both projects and the resources assignment was used in cost analysis.
\end{abstract}

\section{Introduction}

According to the directive of European Parliament and the European Council from April 2009 [1, 2], all member states must prepare legal framework allowing for the application of passive house technology standards to every newly constructed house [3]. Meanwhile current research $[3,4]$ shows that housing in Europe still uses $40 \%$ of the energy produced ( $85 \%$ of the energy in buildings is used for heating, lighting and heating water [4]), and $36 \%$ of $\mathrm{CO} 2$ emission is caused by it. Generalizing the problem one may say that one of the biggest global energy consumers is civil engineering sector [5, 6, 7].

In Poland energy standards for housing were defined in Regulation of the Ministry of Infrastructure and Development regarding technical conditions that must be met by housing and its localization [8]. In line with those standards design practice includes requirements regarding walls insulation, as well as maximum primary energy consumption per $1 \mathrm{~m}^{2}$ of usable area [9]. Changes in the requirements of Technical Standards started in January 2014, the current version has been introduced in January 2017 and the following version will become binding in January 2021. According to the current regulations

* Corresponding author: magdalena.apollo@pg.edu.pl 
buildings cannot exceed the maximum values of heat transfer coefficient $U$ for external walls and the limit of consumption of non-renewable primary energy. The new regulation can be a cause for concern. Is the standard required by the regulation achievable [9] and if it is, then at what cost?

Passive houses do not seem to radically differ from conventional buildings, however through the appropriate design, materials and technology they allow to drastically decrease energy consumption. According to the literature it translates into energy savings of $75 \% \div 90 \%[9,10,11,12]$. This way passive houses are an important part of climate protection. The key question remains the cost the investor has to bear to build a passive house.

There are many solutions to construct a building in line with the requirements of passive house technology. They are differentiated by price and time required for implementation. This study is based on the solution proposed by one of Polish companies, offering technologically integrated products allowing, according to the producer, to build passive houses faster and easier. The goal of this study was to confront producer's claim with reality by comparing time and cost of the same investment using conventional and passive house technology.

The basis for time and cost analysis of the investment was a basic detached house design, partially modified with regards to materials and technology used. In the conventional building the commonly used materials were chosen, in case of passive house styrofoam based materials were selected.

Conclusions of the study are based on the comparison of the two Gantt charts, as defined and optimised in Ms Project. Construction schedule was used to analyse the duration of both projects and the resources assignment was used in cost analysis.

The article consists of four main parts. The first one includes analysis of the literature with regards to passive house requirements. The second part considers the obstacles in the implementation of passive house technology, focusing on the investment costs. The next part is a case study comparing time and cost of construction of a detached house in conventional and passive house technology. That part is the basis for conclusions and practical recommendations that should be considered when making a decision to build a passive house.

\section{Passive house}

\subsection{Technical requirements}

The concept of passive house originated in Darmstadt in 1983. Eight years later the first passive house has been constructed in the same city [3, 4].

A passive house is a building:

- with very low heating energy consumption of $15 \mathrm{kWh} / \mathrm{m}^{2}$ per year, resulting from the use of passive heat sources including: sun, the energy produced by inhabitants, appliances, the heat passively consumed by the house [3],

- which total energy consumption for heating, hot water and electricity should not exceed $120 \mathrm{kWh} / \mathrm{m}^{2}$ per year,

- which leaked air volume cannot be larger than 0.6 of the building volume per hour, measured at the pressure of $50 \mathrm{~Pa}[4]$.

The key aspect in passive house design is the highest possible reduction of heat losses through thermal bridges, walls and ventilation, while at the same time maintaining comfortable micro climate inside. Passive houses do not require conventional heating, 
because the heat is recuperated from ventilation and heating happens through warming the ventilation air $[8,10]$.

Table 1. Criteria for passive houses in Central Europe [11].

\begin{tabular}{|c|l|c|}
\hline No. & \multicolumn{1}{|c|}{ Criteria } & Value \\
\hline 1. & Heating Energy consumption & max. $15 \mathrm{kWh} / \mathrm{m}^{2}$ per year \\
\hline 2. & Heat load demand & max. $10 \mathrm{~W} / \mathrm{m}^{2}$ per year \\
\hline 3. & Cooling demand & max. $15 \mathrm{kWh} / \mathrm{m}^{2}$ per year \\
\hline 4. & Total energy consumption & $\operatorname{max.~} 120 \mathrm{kWh} / \mathrm{m}^{2}$ per year \\
\hline 5. & Leaked air volume (at the pressure of $50 \mathrm{~Pa})$ & $\max .0 .6 \mathrm{change} / \mathrm{h}$ \\
\hline 6. & Frequency of excessive temperatures & $\max .10 \%$ \\
\hline 7. & Area to volume ratio & $\max 0.7$ \\
\hline 8. & Heat transfer coefficient - windows and doors & $\max .0 .8 \mathrm{~W} / \mathrm{m}^{2} \mathrm{~K}$ \\
\hline 9. & Heat transfer coefficient - thermal bridges & $\operatorname{max.} 0.01 \mathrm{~W} / \mathrm{mK}$ \\
\hline 10. & Efficiency of ventilation with heat recovery & $\operatorname{max.} 75 \%$ \\
\hline
\end{tabular}

Based on estimated values a conclusion may be reached that passive housing, depending on the selected heating technology, allows to save even up to $90 \%$ of the cost when compared with conventional building heated with, for example, natural gas. Primary energy consumption at a level of $15 \mathrm{kWh} / \mathrm{m}^{2}$ annually would cost according to [11], depending on the energy source:

- 1.51 of heating oil $/ \mathrm{m}^{2}$ p.a.,

- $1.5 \div 1.7 \mathrm{~m}^{3}$ of natural gas $/ \mathrm{m}^{2}$ p.a.,

- $\quad 4.3 \mathrm{kWh}$ of electricity $/ \mathrm{m}^{2}$ p.a.

For a $190 \mathrm{~m}^{2}$ building the cost of heating with respective sources would be as follows:

- heating oil $-1.51 / \mathrm{m}^{2}$ p.a. $\times 190 \mathrm{~m}^{2} \times 4 \mathrm{PLN}=1140 \mathrm{PLN}$

- natural gas (average) $-1.6 \mathrm{~m}^{3} / \mathrm{m}^{2}$ p.a. $\times 190 \mathrm{~m}^{2} \times 2.5 \mathrm{PLN}=760 \mathrm{PLN}$

- electricity $-4.31 / \mathrm{m}^{2}$ p.a. $\times 190 \mathrm{~m}^{2} \times 0.64 \mathrm{PLN}=523 \mathrm{PLN}$

Passive house technology allows not only to save money or reduce emission of $\mathrm{CO} 2$, but also meets the important criteria of inhabitant's comfort. The use of mechanical ventilation allows constant air replacement, which assures fresh air in all rooms. Humidity is kept at $30 \% \div 50 \%$ and the temperature reaches required levels - in the summer maximum of $25^{\circ} \mathrm{C}$, and in the winter $20^{\circ} \mathrm{C}$ [11]. To meet those requirements, it is necessary to implement many specific solutions. The summary of passive house criteria is presented in Table 1.

\subsection{Obstacles in introduction of passive house technology}

Despite many similarities passive house differs from a conventional one in many architectural, construction and technological aspects, which translates into additional investment cost [10], but also numerous obstacles during implementation. The most important ones include [12]:

- imperfect and incomplete information about standards of passive house technology,

- lack of knowledge regarding introduction and development of relatively new energysaving technologies,

- burdensome processes - regulatory/legal, administration, regarding planning,

- insecurity and risk related to new concepts/technologies, 
- limited access to technology,

- high initial investment cost,

- limited access to financing,

- transaction costs being the result of cooperation of many business entities.

The conducted research confirms that undoubtedly the biggest issue is the cost. According to [13] initial costs of investment in energy-saving buildings may be $4 \% \div 16 \%$ higher than in case of conventional ones, and transaction costs are estimated at $20 \%$ of the investment cost. Other research [12] shows that additional costs of newly build passive houses is between $0 \% \div 17 \%$. With time this cost can be minimized, because of wider access to technology and higher awareness of investors, constructors, architects, etc. As the number of passive houses grows in Germany, Austria and Switzerland, average additional cost decreased to $5 \% \div 8 \%$ [14], and in Sweden it is at the level of $\leq 10 \%$ [15].

In Poland it is estimated that the actual investment cost of passive building is $15 \% \div 20 \%$ higher than in case of conventional construction. At the same time the return on investment is predicted on average after nine years of operation $[11,16]$.

Additional cost of passive house technology not only makes its implementation difficult for private investors, but also makes it impossible for developers to enter the energyefficient market [12]. Another issue is calculation of the period of the return on investment, which depends mostly on the prices of heating energy, which is difficult to predict [10].

\section{Case study}

Acknowledging the observed difficulties in implementation of passive house technology, especially regarding additional costs, the goal of this article was to compare time and cost of building construction in conventional and passive technology. An important aspect is the fact that the time parameter is not considered in the context of obstacles in implementing passive house technology, but to verify producer's declarations. The case study uses a solution proposed by one of Polish companies that offers technologically integrated products, which should make the construction of passive house faster.

The basis of comparison of time and cost of the investment was a basic design of a detached house, which has been modified with regards to materials and technology used. In the conventional technology commonly used materials have been selected, and in case of the passive house styrofoam based materials were chosen. The important thing to note is that both investments were limited to works on core and shell, shell and roof up to closed-in building stage.

The conclusions of the analysis conducted are based on comparison of the two Gantt charts defined and optimised in Ms Project. Construction schedule was used to analyse the time aspect of both projects and resources assignment to tasks allowed to analyse costs.

To conduct appropriate comparative analysis, the following assumptions were made:

- the same scope of works, differentiated only by technology used,

- the same number of employees assigned to specific tasks,

- the same project calendar.

\subsection{Construction and material solutions - passive house}

The design of passive house was based on a modern system by one of Polish producers. This technology was used, among others, for walls, made of hollowed styrofoam blocks. Its core is reinforced and filled with concrete, therefore such modules combine insulation with load-bearing role. Floor slabs are also a systemic solution of the producer, replacing traditional filler blocks. The company claims that the most important advantages of this 
technology are shorter construction time (which is analysed in the following part of this article), high insulation parameters and lack of thermal bridges. Additional modification, when compared to the conventional building, are windows and doors, which low heat transfer coefficient meets the criteria of passive house.

\subsection{Construction and material solutions - conventional house}

The design of the conventional house was meant to meet the basic requirements of the Regulation of the Ministry of Infrastructure and Development from $14^{\text {th }}$ November 2017 regarding technical requirements of buildings and their location [8]. In result the walls have been designed from autoclaved aerated concrete blocks insulated with styrofoam from the outside. Insulation of remaining walls is thinner compared to passive technology. Windows and doors used are adjusted to the criteria of conventional technology, which has major impact on the difference of cost between the two projects.

\subsection{Analysis of the investment time}

Gantt chart defined in Ms Project allowed to establish duration time of both projects. In case of the passive house it was 91.5 working days, while for the conventional house 104 working days. The investment duration time of the passive house was shorter by 17 calendar days, confirming the producer's declaration.

As the scope of construction works was the same, the duration time for majority of tasks is also equal. Some changes, such as thickness and type of insulation, using different windows and doors, did not affect the time necessary to complete the project. Figure 1 presents only those tasks where the duration time between the two compared solutions was different.

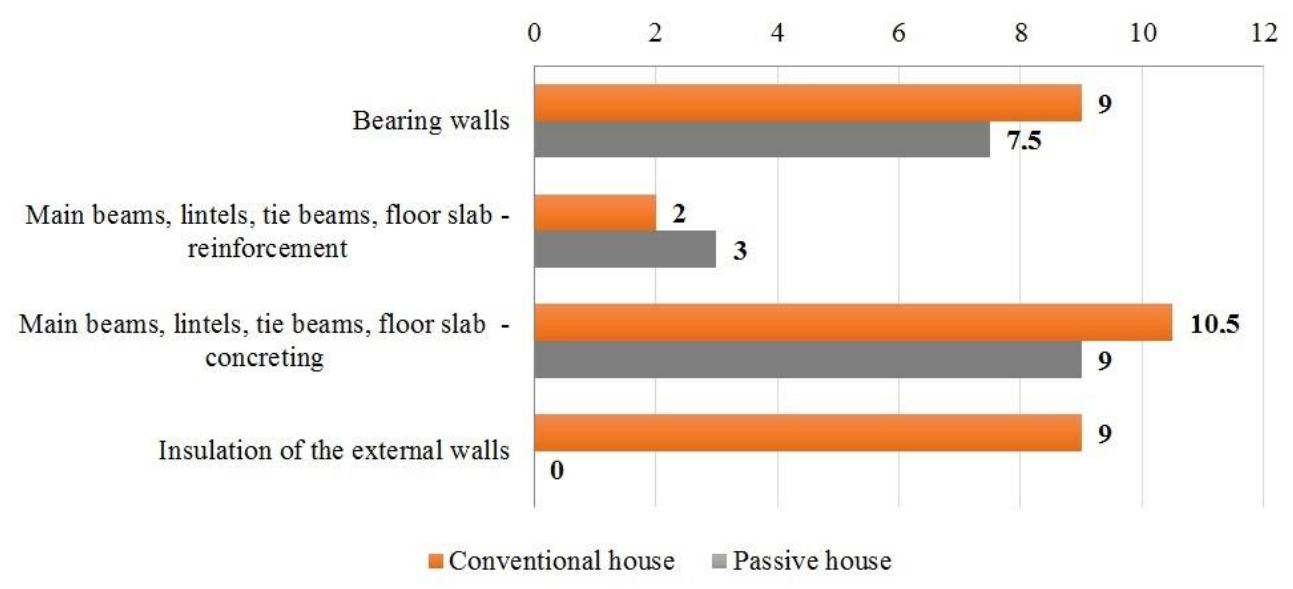

Fig. 1 Duration time of the selected tasks for passive and conventional house [working days].

The task that impacted the project completion time the most was construction of loadbearing walls. The effort required to construct those walls in the technology of company $x$ is estimated (depending on the experience of the workers) on average at $0.5 \mathrm{~h} / \mathrm{m}^{2}$, while construction of the conventional walls takes $0.8 \mathrm{~h} / \mathrm{m}^{2}$. This data shows that the time necessary to build a wall from styrofoam blocks is $40 \%$ shorter than the time needed to build in conventional technology. However it should be noted that duration time to reinforce and fill the styrofoam wall with concrete has to be added. As a result, the difference in time is rather small ("Load-bearing walls - ground floor") or none ("Load- 
bearing walls $-1^{\text {st }}$ floor"). Small differences in duration time are also related to the relatively small size of the building. It is estimated that with the larger surface area the time difference will increase, resulting in time savings. The key advantage of the chosen passive house technology is the possibility of constructing the walls together with insulation, which eliminates the need of additional building insulation. In the analysed project it shortened the investment time by 9 working days.

Additional differences in the duration time can be observed in constructing main beams, lintels, tie beams or floor slabs. The differences are mostly caused by the various types of reinforcement used. Additionally, the used passive technology required a larger number of main beams (some elements of this technology are not suited to long lintels).

\subsection{Analysis of the investment cost}

As previously mentioned, the most important factor limiting every investor is the cost. The presented analysis shows the difference in cost of constructing a detached house in both technologies, indicating at the same time the elements that are major reasons for it.

Construction cost of the passive house has been estimated at 390206 PLN, and the conventional house at 283244 PLN. This large difference is caused mostly by the technology of load-bearing walls. Walls of the passive house have been constructed using styrofoam blocks but also reinforcement and concrete. On the other hand, load-bearing walls built in passive technology do not require additional external insulation. It does not change the fact that the cost of building walls is three time lower in case of conventional technology. Similar situation happens in case of floor slabs. Here the conventional technology is almost four times cheaper. Additional significant element are windows and French-windows. The application of higher standards increased the cost of passive house by app. $15 \%$.

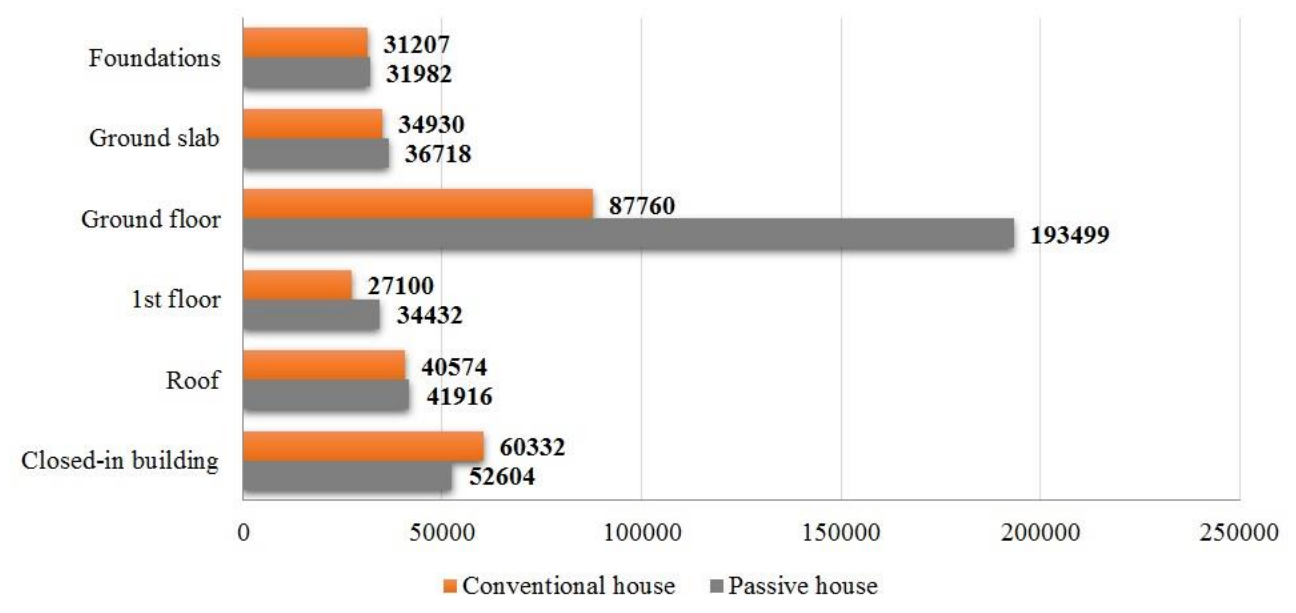

Fig. 2 The value of lump sum items for both technologies [PLN].

Figure 2 shows the values of lump sum items for both projects. The cost for „Foundations”, „Ground slab” and „Roof” shows insignificant variance. It is caused mainly by the different thickness and quality of insulation materials. The item with the highest difference is "Ground floor", which is caused by the different technology used to construct load-bearing walls. This translates into an enormous change in cost, in case of "Ground floor" it was 106000 PLN, and in case of " 1 st floor" 7500 PLN in favour of the conventional method. The last position generating the difference is "Closed-in building". 
In this case the cost is unfavourable for the conventional method, mostly due to the required additional building insulation.

All of the above-mentioned factors increase the cost of building a detached house in passive technology by over 100000 PLN when compared to conventional technology. The data shows that construction of a passive house if $38 \%$ more expensive than a conventional one, although it should be noted that the scope of analysed project is limited, which is not without impact to the value of estimated percentage increase of investment cost.

\section{Conclusions}

The goal of this article was to present an influence of passive house technology on time and cost of construction investment. The analysis was based on the project which limited scope could have impacted the resulting additional cost of constructing passive house, nevertheless the results allow to formulate some general conclusions.

The technology used in the study, offered by one of the Polish producers, allowed to confirm shorter time required to complete investment. It is difficult to undoubtedly conclude if shortening the investment time by app. 14\% when compared with conventional technology is sufficient justification for selecting this solution. Nevertheless it is estimated that in case of wider scope of works and long-term investments this difference may become significant.

Cost analysis allows to draw more explicit conclusions. Application of passive technology increased the investment cost by $38 \%$, which translated to 108000 PLN more than in case of conventional technology. Additionally, transaction costs should be considered; it is estimated that they would also be higher than in case of conventional building.

Considering only the cost aspect, the above conclusion may discourage potential investors. However, it is also important that passive house technology results in significantly lower energy consumption, so operating costs when compared to conventional house are a lot lower and in the longer run bring the return on investment. Additionally, to assess the entirety of costs associated with constructing a passive house it is recommended to use life-cycle cost (LCC) methodology, which allows to select the most financially beneficial option [17, 18]. Basing only on initiation investment cost may result in selecting the solution that will generate high operation cost in the long term [7].

Additional aspect supporting passive house technology is wider spread access and knowledge of Building Information Modelling (BIM) [19, 20]. Research shows that the application of BIM may result in lower transaction costs, but also provide much more certainty and efficiency in the process of design and project implementation [21].

\section{References}

1. Directive $2009 / 28 / \mathrm{EC}$ of the European Parliament and of the Council, Off. J.Eur. Union (2009)

2. Directive $2009 / 29 / \mathrm{EC}$ of the European Parliament and of the Council, Off. J.Eur. Union (2009)

3. G. L. Ionescu. Passive house. Journal of Applied Engineering Sciences 7(20), Issue 1, 23-27 (2017)

4. M. Mihai, V. Tanasiev, C. Dinca, A. Badea, R. Vidu. Passive house analysis in terms of energy performance. Energy and Buildings 144, 74-86 (2017) 
5. L. Pérez-Lombard, J. Ortiz, C. Pout. Energ. Buildings 40, 394-398 (2008)

6. K. Sperling, B. Möller. Appl Energy 92, 831-842 (2012)

7. A. Stec, A. Mazur, D. Słyś. Evaluating the financial efficiency of energy and water saving installations in passive house. E3S Web of Conferences 22, 00168 (2017)

8. Rozporządzenie Ministra Infrastruktury i Budownictwa z dnia 14 listopada 2017 r. zmieniające rozporządzenie $\mathrm{w}$ sprawie warunków technicznych, jakim powinny odpowiadać budynki i ich usytuowanie. (Dz.U. 2017 poz. 2285)

9. A. Węglarz. Wymagania prawne odnośnie standardu energetycznego budynków. Retrieved January 20, 2018 from https://www.budujemydom.pl/domypasywne/24103-wymagania-prawne-odnosnie-standardu-energetycznego-budynkow

10. R. Miniotaite. Technical - Economic Research for Passive Buildings. IOP Conf. Series: Mat. Sc. and Eng. 245 (2017)

11. K. Jarocka. Budynki niskoenergetyczne 3/13 (2013)

12. B. Kiss. Exploring transaction costs in passive house-oriented retrofitting. J. of Clean. Prod. 123, 65-76 (2016)

13. A. Audenaert, S. H. De Cleyn, B. Vankerckhove, Economic analysis of passive houses and low-energy houses compared with standard houses. Energy Policy 36 (1), 47-55 (2008)

14. PHI. Are Passive Houses Cost-effective? Retrieved January 19, 2018, from http://passipedia.passiv.de/passipedia_en/basics/affordability/investing_in_energy_effi ciency/are_passive_houses_cost-effective (2012)

15. A. Blomsterberg. Low-energy Houses e a Study of Different Concepts. No. EBD-R09/28. Lund University, Lund (2009).

16. M. Apollo, E. Miszewska-Urbańska. Analysis of the increase of construction costs in urban regeneration projects. Adv. in Sc. and Tech. - R. J. 9, No. 28, 68-74 (2015)

17. B. Grzyl, E. Miszewska-Urbańska, M. Apollo. The life cycle cost of a building from the point of view of environmental criteria of selecting the most beneficial offer in the area of competitive tendering. E3S Web of Conferences 17/ 00028 (2017)

18. H. Anysz, J. Zawistowski. Kontrola czasowo-kosztowa postępu robót budowlanych metodą wartości wypracowanej z wykorzystaniem programu MS Project. Conference paper (2017)

19. B. Grzyl, E. Miszewska-Urbańska, M. Apollo. Building Information Modelling as an opportunity and risk for stakeholders involved in construction investment process. Procedia Eng. 196, 1026-1033 (2017)

20. K. Kaczorek, Sz. Janczura. Korzyści z projektowania w BIM. Przewodnik Projektanta, 6-9 (2017)

21. A. Pitts. Passive House and Low Energy Buildings: Barriers and Opportunities for Future Development within UK Practice. Sustainability 9 (2017) 